names. Eumeles is especially remarkable, and we would invite the attention of conchologists who hunt slugs (in old collections of museums and elsewhere) to the unusual arrangement of the tentacles in this genus, and to the fact that a number of Rafinesque's species are still at large.

The genus Meghimatium, v. Hasselt, 1824, was founded on a species of this genus from Java, and was quite recognizably described. The names Tebennophorus, Binn., and Incilaria, Benson, were both proposed in 1842, the probable priority being in favour of the first.

Morse in 1864 established the genus Pallifera for a species with ribbed jaw.

This review shows that several names for the genus, more or less certainly applying to it, were proposed anterior to 1842, the date of Tebennophorus. Of these names Phitomycus and Meghimatium are the only ones available, Eumeles and Limacella being clearly inapplicable. Since continental authors generally have adopted the name Philomycus, it seems advisable to retain that designation for the genus if Tebennophorus must be rejected.

Philadelphia, December 2, 1890.

XXII.-Natural History Notes from H.M. Indian Marine Survey Steamer 'Investigator,' Commander R. F. Hoskyn, R.N., commanding.-No. 21. Note on the Results of the last Season's Deep-sea Dredging. By J. Wood-Mason, Superintendent of the Indian Museum, and Professor of Comparative Anatomy in the Medical College of Bengal, and A. Alcock, M.B., Surgeon I. M. S., Surgeon-Naturalist to the Survey.

[Continued from p. 19.]

\title{
Phylum APPENDICULATA.
}

Branch CH \& TOPODA.

Fragments from mud from 89 to 93 fathoms, from 1310 fathoms, and from sand from 98 to 102 fathoms, in the Bay of Bengal. 
Branch A R THROPODA.

Class C R U S T A C E A.

Of this class fifty-three species were obtained, of which fifty-one belong to the Malacostraca, and two to the Entomostraca.

\section{Grade $M A L A C O S T R A C A$.}

Amongst the fifty-one species belonging to this subclass every order except Amphipoda and Cumacea is represented, as follows:-

\section{Order SCHIZ O P O D A.}

Family Lophogastridæ.

\section{Gnathophausia, Suhm.}

At Stations 100 and 102 , at 840 and 920 to 690 fathoms respectively, two fine specimens were obtained. They are of the usual uniform deep lake-colour, and they represent the two sections into which Sars has divided this genus.

\section{Gnathophausia Sarsii, sp. n., Wood-Mason.}

Belongs to the second section of the genus, in which it is nearest allied to Gnathophausia Willemoesii. The carapace covers the basal third of the first abdominal somite and has its dorsal spine produced as far as the posterior end of the third abdominal tergum; its extreme edge is expanded at the postero-inferior angle into a conspicuous rectangular lamina, into which neither its lower lateral keel nor its raised rim enters. The rostrum, which has lost its tip, appears to have been of the same form and proportions. Ocular and antennal spines well developed, divergent; the former are slightly curved and rather longer and slenderer than the latter. There are no branchiostegal spines. The upper half of the posterior margin of the carapace on each side and the lateral edges of the dorsal spine are minutely denticulated. Each of the five anterior abdominal terga has a dorsal keel produced posteriorly into a short sharp spine, and two subdorsal keels, and the posterior lobes of the pleura acuminate. The telson is tricarinate, having a fine median carina in addition to the much coarser sublateral ones, and appears to be more produced at the tip than in any other species.

Length from tip of rostrum to apex of telson 75 millim. 
2. Gnathophausia gracilis, Suhm, var. brevispinis.

Gnathophausia gracilis, Suhm, Trans. Linn. Soc. Lond., Zool. ser. 2, vol. i. p. 33, pl. ix. fig. 1 ; Sars, Chall. Rep. vol. xiii. pt. xxxvii.

Schizop. p. 48, pl. vii. figs. 6-10.

Our specimen differs from the one figured by Suhm in the small size of the spines of the infero-posterior corners of the carapace, the lower one of which is reduced to a minute outstanding point only visible when the animal is viewed from above. It may perhaps be found to differ also in the form and relative proportions of the wing-like antennal and branchiostegal spines, as well as in other respects, when better specimens of the typical form shall be available for comparison. In the meantime it will suffice to indicate it as a variety.

Length from tip of rostrum to apex of telson 82 millim.

Both the above specimens would appear to be males.

\section{Order D E C A P O D A.}

\section{Family Penæidæ.}

\section{Hymenopenæus, S. I. Smith.}

\section{Hymenopenceus ? microps, S. I. Smith.}

Hymenopenceus? microps, S. I. Smith, Ann. Rep. Comm. Fish. 1884, p. 413 [69], pl. x. fig. 1.

Three specimens have been obtained - a male and a female from Station 104, 1000 fathoms, and a male from Station 105, 740 fathoms - of a species answering to Prof. Smith's diagnosis. They are all coloured a very deep vinous purple mottled with black, and are still of a deep wine-red, except the last two pairs of legs.

\section{Solenocera, Lucas.}

4. Solenocera Hextii, sp. n., Wood-Mason.

A strikingly beautiful Penæid of a bright pink colour was obtained in fair abundance at Stations 81 and 96 , in 89 to 102 fathoms. It is remarkable for the great development of the respiratory mechanism in all its parts, especially the branchial chambers, the afferent and efferent divisions of which are sharply defined externally by the special prominence of the coincident parts of the branchiostegite, and also for the form of the antennules. These are shorter 
and broader than those of any of the described species, and their inner or ensheathing branch is much less deeply semitubular, being indeed only slightly incurved along its lower margin and forming by its union with its fellow of the opposite side a strongly compressed tube, of which the lumen appears to be entirely filled by the two flat outer or olfactory branches of opposite sides. There is little doubt that this special development of the antennules has a causal relation to the presence of delicate sense-organs, which, owing to some unknown circumstances in the surroundings of the animal, stand in special need of protection.

This form had previously been found at 65 fathoms off Chittagong, at 68 fathoms off the Mahánadi Delta, and at 70 fathoms off the Godávari Delta.

\section{Gennadas, Spence Bate.}

\section{Gennadas parvus, Spence Bate.}

Gennadus parvus, Spence Bate, Ann. \& Mag. Nat. Hist. (5) viii, p. 191 ; and 'Challenger' Macrura, 1888, p. 340, pl. lix.

A male and a female from Station 101, 922 fathoms, and Station 103, 1260 fathoms respectively, belong, there is little doubt, to the above species, which has such a wide geographical and bathymetrical range. Both were of a uniform deep lake-colour. Amalopenceus elegans, S. I. Smith, is probably the same species.

\section{Hepomadus, Spence Bate.}

\section{Hepomadus? tener, S. I. Smith.}

Hepomadus ? tener, S. I. Smith, Ann. Rep. Comm. Fish. 1884, p. 409 [65], pl. ix. figs. 7 and 8.

A female specimen was obtained at Station 97, 1310 fathoms, but is too much macerated for exact determination. Its colour in the fresh state was bright orange.

\section{Hemipenaus, Spence Bate.}

\section{Hemipenceus Carpenteri, sp. n., Wood-Mason.}

Is closely allied to Hemipencus spinidorsalis, Spence Bate, but differs in the following relations:- The thoracic legs are shorter, the three anterior pairs have the ischiopodite stouter, and longer in proportion to the succeeding joint, and the two last pairs are more filiform; the exopodites of the abdominal appendages are much longer; the rostrum is much weaker 
and also shorter, barely reaching the apex of the basal joint of the antennulary peduncle; the cervical suture appears to be more distinct in its dorsal part; and the hooked spine of the third abdominal tergum springs right from the anterior end instead of from the middle of the crest.

One female specimen from Station 97, 1310 fathoms.

Colours in the fresh state bright orange.

Length from tip of antennal scale to tip of caudal swimmeret in a straight line 118 millim.; length of exopodite of first abdominal appendage 42 millim.; length of carapace from middle of posterior margin to tip of rostrum 32.5 millim.; length of third thoracic leg 46 millim.

\section{Family Sergestidæ.}

Sergestes, Milne-Edwards.

8. Sergestes bisulcatus, sp. n., Wood-Mason.

Closely allied to S. robustus and S. mollis, S. I. Smith, but readily distinguishable from both in the cervical being no less distinct across the back of the carapace than the gastrohepatic groove. It differs from $S$. mollis, and apparently agrees with $S$. robustus, in the relative proportions of the joints of the antennulary peduncles and in the form and proportions of the eyes, which are comparatively short and very distinctly widened from base of peduncle to apex of depressed hemispherical cornea; and it agrees with S. mollis and differs from S. robustus in the size of the rostrum.

Colour in the fresh state deep crimson-lake.

A female from Station 100, 840 fathoms, and a male from Station 105, 740 fathoms.

Length of male from tip of rostrum to apex of telson 60 millim., of female 63 millim.

\section{Sergestes ? arcticus, Kröyer.}

Sergestes arcticus, Kröyer, Monog. Fremstill af Kraeb. Sergestes, pp. 24, 60, tabs. iii. and v.; Spence Bate, 'Challenger' Macrura, p. 436.

Our only specimen wants the spine on the outer margin of the exopodite of the caudal swimmeret said to be present in S. arcticus.

Colour in the fresh state deep crimson-lake. From Station 101, 922 fathoms. 


\section{Family Glyphocrangonidæ.}

\section{Glyphocrangon, A. Milne-Edwards.}

The described species may, with the undescribed ones in our collection, be artificially arranged in three groups as follows :-

(1) Species with the anterior moiety of the fourth or lateral crest * produced and expanded at its anterior end into a single huge vertically-compressed spine, which extends far beyond the level of the supraorbital margin of the carapace, and with the ridges and other elevations of the dorsal integument generally more or less sharp and roughly tuberculose.- $G$. aculeatum, A. M.-Edw., Spence Bate (=G. Agassizii, S. I. Smith), ( ${ }^{\prime}$.regalis, Spence Bate, and the following species, which, though not belonging to last season's collection, we think may be appropriately described here.

10. [Glyphocrangon investigatoris, sp. n., Wood-Mason.

Allied to $G$. aculeata and $G$. regalis, but distinguishable at a glance from the former by the posterior moiety of the third carapacial crest not being produced anteriorly into a spine and from both by its much more tuberculose cephalothorax and abdomen. From the latter, to which it is the more nearly allied, it further differs in having the posterior moiety of the third and fourth crests dentate and the lateral margins and carinæ of the telson sharply tuberculate for rather more than the basal third of their length. From $G$. spinicauda, A. M.-Edw., which, from Spence Bate's remark, would appear also to belong to this group, it differs in having the anterior moiety of the fourth crest undivided.

"The ground-colour" of this striking form "is old ivorywhite with orange-white markings on tips of spines, \&c.; the eyes are magenta." (G. M. Giles.)

Twenty-four specimens, of which three are adult (two of them ovigerous) females, were obtained at a single haul in lat. $19^{\circ} 35^{\prime}$ N., long. $92^{\circ} 24^{\prime}$ E., in 272 fathoms.

Length of rostrum 14.5 millim., of carapace from orbital to posterior margin 25 millim., of abdomen 51 millim.; total

* To facilitate the following descriptions the carapacial crests, of which there are seven pairs, may be named "dorsal," "subdorsal," "sublateral," "lateral," " submarginal," " antemarginal," and "marginal," or may be simply numbered 1 to 7 in the order of their succession from the middorsal line downwards on each side. The specific characters are taken from the four uppermost. 
length 90.5 millim.; width between points of spines of lateral crests 20 millim.

A single adult (ovigerous) female was subsequently obtained in lat. $20^{\circ} 17^{\prime} 30^{\prime \prime} \mathrm{N}$., long. $88^{\circ} 50^{\prime} \mathrm{E}$., in 193 fathoms, in company with Nephropsis Carpenteri.]

(2) Species with the anterior moiety of the fourth crest divided into two parts produced anteriorly into moderate spines, the anterior of which never approaches the level of the supraorbital margin, and with the ridges and other elevations of the dorsal integument more or less sharp and roughly tuberculose.-G. sculptus, S. I. Smith, G. granulosis, $\dot{G}$. podager, and $G$. rimapes, Spence Bate, and the following:-

\section{Glyphocrangon priononota, sp. n., Wood-Mason.}

Allied to G. sculptus and G. granulosis, but distinguishable at a glance from the former by the great strength and distinctness of all the crests, but especially of the dorsal and subdorsal (first and second), which are strongly toothed; by the posterior moiety of the sublateral (third) crest not terminating anteriorly in a tubercle; by the anterior moiety of the lateral (fourth) crest being merely divided by a notch and not reduced to two spines; by its more strongly tuberculate abdomen; by the pleura of the fifth abdominal somite being bispinose instead of trispinose; by the form of the dactylopodites of the fourth and fifth pair, which are simply pointed; by the teeth at the base of the rostrum being larger than the teeth of the rostrum itself ; and probably in other details. It apparently agrees with $G$. granulosis in the strength and armature of the dorsal and subdorsal crests, but it differs in its narrower body; in the rostrum extending fully one third of its length beyond the antennulary peduncle; in the posterior moieties of the sublateral and lateral (third and fourth) crests not being tuberculose, and the former of them not ending anteriorly in a strong cusp; and in the spines of the anterior moiety of the lateral (fourth) crest not being so large. From comparison with $G$. podager and $G$. rimapes it is altogether excluded by the simple dactylopodites of its fourth and fifth pairs of legs.

Two males and one female from Station 104, 1000 fathoms.

Colours in the fresh state deep pink; colour of eyes in spirit dark purple.

Length of rostrum 21.75 millim., of carapace from orbital to posterior margin 22 millim., of abdomen 59 millim.; total length 107 millim. 
(3) Species in which the anterior moiety of the fourth crest is undivided and terminates anteriorly in a single small spine, and the ridges and tubercles of the occasionally pubescent dorsal integument are more or less blunt and smooth. $-G$. longirostris, S. I. Smith, G. hastacauda and G. acuminata, Spence Bate, ?G. nobilis, A. Milne-Edwards, and the two following species, of which the first, though belonging to the collection of a previous season, may fitly be introduced here :-

\section{2. [Glyphocrangon Gilesii, sp. n., Wood-Mason.}

Distinguished not only from all the other members of its group, but also from all the other species of the genus, by possessing the full complement of complete crests on both divisions of the carapace, the anterior moiety of the third crest being developed and produced anteriorly into a small spine just as in the case of the fourth crest. The gastric moiety of the second crest is divided into three parts, the foremost of which is produced into a minute spinule. There is a small tubercle in the gastro-rostral groove between the front ends of the dorsal (first) crests. With these exceptions the integument of the carapace is quite smooth and, except on the summits of the crests, which are very distinctly foveolaterugose, somewhat polished. Except for the median crests and transverse grooves the sculpture of the abdominal terga is obsolete. The pleura of the four intermediate somites are bispinose at the extremities, with the smaller tooth posterior in the first three and anterior in the last, where the posterior spine rivals the single spine of the last pleuron. The antennal spine is longer and horizontally more expanded than the antero-lateral, which is invisible from above. The dactylopodites of the fourth and fifth pairs of legs are lanceolate and simply acute at the tips.

A single female was obtained on the 8th December, 1887, eight miles south-east of Cinque Island, in the Andaman Sea, in 500 fathoms; bottom green mud.

The colour in spirit is ivory-white, with the tips of the spines, rostrum, and telson and the summits of the crests pale orange.

Length of rostrum 11 millim., of carapace $13 \cdot 75$, of abdomen 33 ; total $56 \cdot 75$ millim.]

\section{Glyphocrangon unguiculata, sp. n., Wood-Mason.}

Closely allied to the preceding; differs in the carapace and abdomen being covered with a very thin, filmy, delicate, and 
deciduous velvety pubescence; in the anterior moiety of the sublateral crest being reduced to a thin, interrupted, unarmed wrinkle; in the anterior or gastric moiety of the subdorsal crest being broken up into a diffused, coarsish, subtuberculose wrinkling, terminated anteriorly by a spine; in the dorsal crests being subtuberculose; in the antennal and anterolateral spines being more divergent in a side view, or, in other words, less horizontal; in the postero-inferior angle of the second and third abdominal pleura being angular rather than spinose ; and, finally, in the outer margin of the dactylopodites of the fourth and fifth pair of legs being produced near the apex into a minute incurved claw.

Two egg-laden females from Station 105, 740 fathoms.

Colour in life delicate pink; eyes in spirit dark purple.

Total length from tip of rostrum to apex of telson 73.5 millim.; of carapace, from supra-orbital to posterior margin, 18 millim.; of rostrum, from supra-orbital margin to apex, 13 millim.; of abdomen with telson 44 millim.

\section{Family Miersiidæ.}

\section{Ephyrina, S. I. Smith.}

Ephyrina, S. I. Smith, Proc. U. S. Nat. Mus. 1885, p. 506.

Tropiocaris, Spence Bate, 'Challenger' Macrura, 1888, p. 835, pl. cxxxvi. fig. 1 .

\section{Ephyrina Hoskynii, sp. n., Wood-Mason.}

Closely allied to Ephyrina Benedicti, S. I. Smith (= Tropiocaris planipes, Spence Bate), but differs in having the carapace and the rostrum shorter, the latter not quite reaching the corneæ and terminating abruptly in a vertical sinuous margin; the eyes apparently smaller, and the third abdominal segment non-produced.

This exceedingly delicate specimen was in the fresh state of a dark red colour.

From Station 105, 740 fathoms.

Length from front margin of rostrum to apex of telson 60 millim.

Hoplophorus, Milne-Edwards.

15. Hoplophorus Smithii, sp. n., Wood-Mason.

A small species from Station 62, 1439 fathoms, and Station 103, 1260 fathoms, apparently distinguished from previously described species by the smallness of the spine at the postero- 
inferior angle of the carapace and by the pleura of the first abdominal somite being strongly emarginate, but not spinose, at its antero-inferior angle. The efferent branchial channel is extremely large. The rostrum, which is $\frac{13}{8}$-toothed, descends to the first infra-marginal tooth, whence it is straight and slightly ascendant; its length, measured from its tip to the supra-orbital margin, is equal to the interval between the last-named point and the hinder margin of the second abdominal somite. The spiniform process of the third abdominal tergum is more than twice as large as those of the two other segments, which are subequal.

Colours in life bright pink, in spirit strongly iridescent.

The specimen from Station 103 measures 50 millim. from tip of rostrum to apex of telson; it was alive and active when brought on board.

\section{Acanthephyra, A. Milne-Edwards.}

16. Acanthephyra curtirostris, sp. n., Wood-Mason.

Closely allied to $A$. acutifrons, Spence Bate, differing therefrom in its shorter and smaller carapace and in its much less produced rostrum, which does not reach beyond the middle of the terminal joint of the antennulary peduncle and is armed on its upper margin with nine minute saw-like teeth, on its lower with a single strongish spine. The ocular papilla embraces the cornea.

Two males from Station 100, 840 fathoms, and one from Station 104, 1000 fathoms.

Length from tip of rostrum to apex of telson 85 millim.

17. Acanthephyra brachytelsonis, Spence Bate.

Acanthephyra brachytelsonis, Spence Bate, 'Challenger' Macrura, 1888 , p. 753 , pl. cxxvi. fig. 7 .

From Station 104, 1000 fathoms, eight specimens, of which two are fine adult males, and two mutilated specimens from 740 fathoms at Station 105.

Colours in the fresh state deep crimson-lake.

Length from tip of rostrum to apex of telson about 120 millim.

\section{Family Alphæidæ.}

Dorodotes, Spence Bate.

18. Dorodotes reflexus, Spence Bate.

Dorodotes reflexus, Spence Bate, 'Challenger' Macrura, p. 678, pl. cxvi. fig. 3 . 
Six fine males from Station 97, 1310 fathoms, coloured bright pink, and one ovigerous female of moderate size from Station 62,1439 fathoms.

The eggs are of two sizes and colours, the smaller being light brown, the larger bright pink like the mother, the difference in colour and size being due to the formation of an embryo.

When brought on board the carapace of every specimen was covered with a thick greasy secretion, probably cuticular in origin : in spirit the carapace still has a greasy appearance.

\section{Heterocarpus, A. Milne-Edwards.}

\section{Heterocarpus Alphonsi, Spence Bate.}

Heterocarpus Alphonsi, Spence Bate, 'Challenger' Macrura, 1888, p. 632 , pl. cxii. fig. 1 .

Nine specimens, of which four are adult males, one an ovigerous female, and four immature males, were obtained at Station 105, 740 fathoms.

The colour in the fresh state is deep pink.

Length of male, from tip of rostrum to apex of telson, 137 millim.; of female 163 millim.

\section{Family Pasiphäidæ.}

\section{Parapasiphä, S. I. Smith.}

20. Parapasiphaë latirostris, sp. n., Wood-Mason.

This fine species is distinguished by its high and short foliaceous rostrum, which barely reaches to the extremity of the eyes, is strongly arched above, is bispinose at its apex, and is preceded by five or six small teeth on the gastric region; by the cornex occupying the whole extent of the apex of the depressed peduncles; and by the crest of the fourth abdominal tergum being produced backwards in the middle line into a sharp spine.

The single specimen is a female.

It was obtained at Station 105, in 740 fathoms, and in the fresh state was coloured a deep lurid red.

Length 103 millim.

\section{Parapasiphaë Alcocki, sp. n., Wood-Mason.}

A smaller species taken at Station 101, 922 fathoms. It is distinguished by its short eye-stalks and globular corneæ, 
and by the form of the rostrum, which terminates abruptly a little behind the anterior margin of the carapace in a vertical sinuous edge, much as in Ephyrina Hoskynii.

Colour in the fresh state deep crimson-lake.

One male specimen, measuring 64 millim. from the anterior margin of carapace to apex of telson.

\section{Family Nematocarcinidæ.}

Nematocarcinus, A. Milne-Edwards.

22. Nematocarcinus tenuipes, Spence Bate.

Nematocarcinus tenuipes, Spence Bate, 'Challenger' Macrura, 1888, p. 812 , pl. cxxxii. fig. 6 .

Station 97, 1310 fathoms, four specimens; Station 104, 1000 fathoms, two specimens.

Colours in the fresh state bright orange.

\section{Family Homaridæ.}

Phoberus, A. Milne-Edwards.

23. Phoberus cacus, A. Milne-Edwards, var. nov. sublevis, Wood-Mason.

Phoberus cacus, A. Milne-Edwards, Ann. Sci. Nat. (6) xi. 1881, 4, p. 1. Phoberus tenuimanus, Spence Bate, 'Challenger' Macrura, 1888, p. 171, pls. xxi., xxii.

Our specimen differs from those of the 'Blake' and 'Challenger,' which seem to be identical, only in having one spine instead of three on the upper margin of the rostrum, and the carapace and dorsal integument generally less spinose.

Length from tip of rostrum to apex of telson 118 millim.; from extremity of extended chelæ to apex of telson 177 millim.

Colour delicate pink.

One male specimen from Station 105, 740 fathoms.

Nephropsis, Wood-Mason.

24. Nephropsis atlantica, Norman.

Nephropsis atlantica, Norman, Proc. Roy. Soc. Edinb.1881-82, vol. xi. p. 684 .

Six specimens (four males and two females), from Station 105, 740 fathoms, agreeing with Canon Norman's excellent description of the male. 
The species is abundantly distinct from N. Agassizii (=aculeatus), which, so far as the figure goes, is indistinguishable from $N$. Stewartii.

Fig. 4.

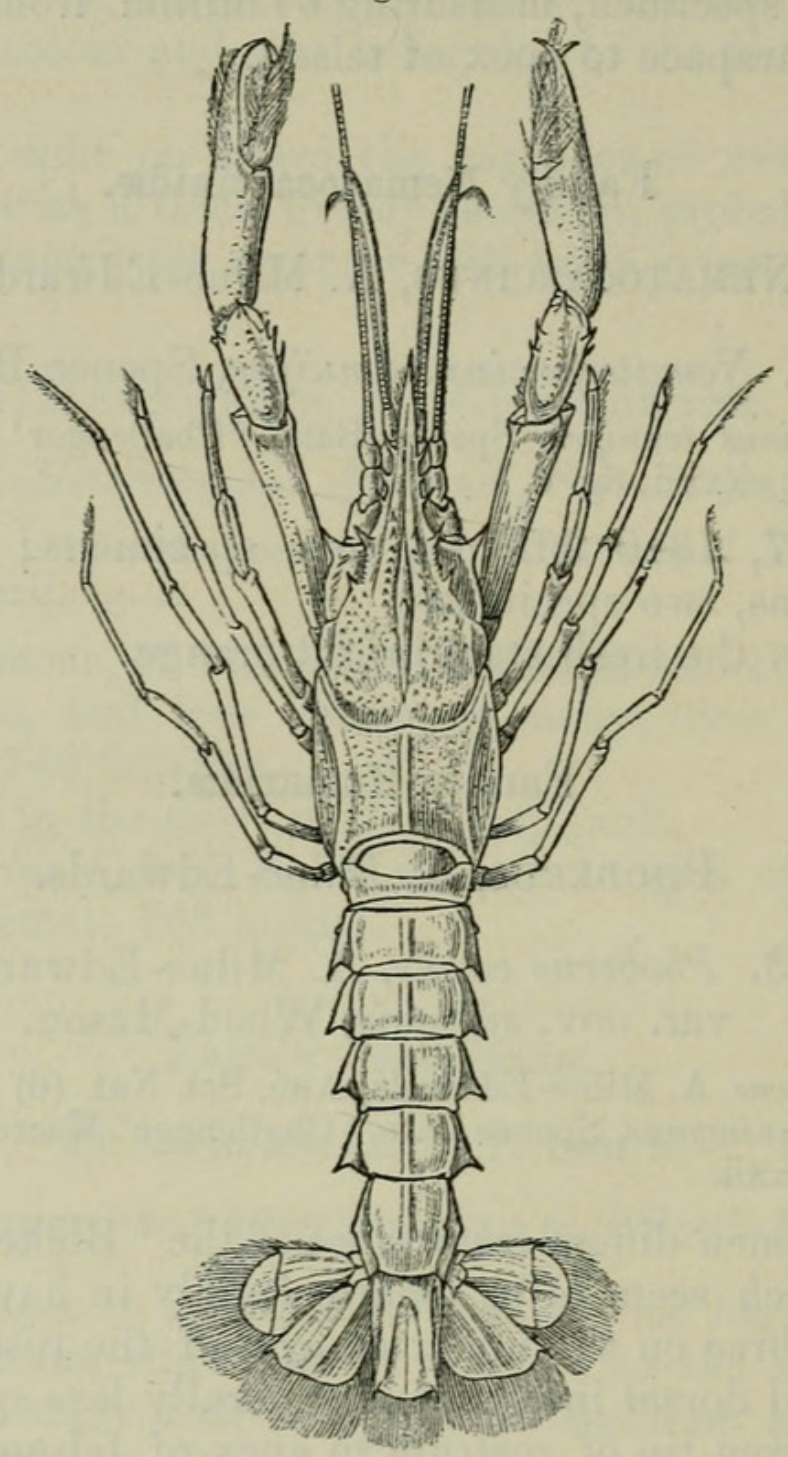

Nephropsis atlantica, Norman, $\delta^{*}$, nat. size.

Of our specimens one has three pairs, one two and a half pairs, three two pairs, and one a pair and a half of lateral spines on the rostral margins.

Colours in life pink, with a broad white longitudinal dorsal stripe.

Family Thalassinidæ.

Callianassa, Leach.

25. Callianassa, sp.

Two specimens, probably male and female, of a small species from Station 76, 93 fathoms.

Colours in life deep-sea pink. 


\section{Family Eryontidæ.}

Willemoesia, Grote.

\section{Willemoesia forceps, A. Milne-Edwards.}

Willemoesza forceps, A. Milne-Edwards, Bull. Mus. Comp. Zool. vol. viii. 1880 , p. 64.

One female specimen, of a bright pink colour, in length (measured from front margin of carapace to apex of telson) 99 millim., from Station 62, 1439 fathoms; and one male and one female specimen, of a milk-white colour, measuring respectively 84 millim. and 82 millim., from Station 97, 1310 fathoms.

\section{Pentacheles, Spence Bate.}

\section{Pentacheles, sp.}

A single specimen, with the chelipeds wanting, from Station 105,740 fathoms.

Colour pale pink.

\section{8. ? Pentacheles (? immature).}

At Station 102, 920 to 690 fathoms, a very remarkable specimen was obtained, which may best be described for our present purpose as a Pentacheles with a globularly inflated carapace and all the spines of its dorsal integument of larvalike length and sharpness. It recalls a good deal the curious larva which Spence Bate has described and figured ('Challenger' Macrura, fig. 30, after a drawing by Willemoes von Suhm) under the name of "Eryoneicus ccecus." We believe that notwithstanding its great size-36 millim. in length-it is an immature form of some species of Pentacheles, bearing to the adult form a relation similar to that which exists between a just-hatched and an adult crayfish.

Our specimen speaks to the accuracy of Willemoes von Suhm's drawing of that which, there is little doubt, is only a very much younger stage.

Length 36 millim.

Colour in the fresh state pink.

Family Parapaguridæ.

Parapagurus, S. I. Smith.

29. Parapagurus abyssorum, A. Milne-Edwards, MS.

Parapagurus abyssorum, Henderson, 'Challenger' Anomura, p. 87, pl. ix. fig. 2.

One fine specimen at Station 105, 740 fathoms.

Colour in the fresh state pink. 
The animal was sheltered in a fine colony of an Epizoanthus similar to the figure of Epizoanthus paguriphilus, Verrill, in Professor S. I. Smith's paper in Proc. U. S. Nat. Mus. vol. iii. 1883.

\section{Pagurodes, Henderson.}

\section{Pagurodes, sp.}

All the dead shells of Rostellaria delicatula brought up at Stations 81 and 96 were tenanted by a small hermit-crab which fits fairly well into this genus. Its colour in the fresh state was bright pink, similar to the colour of the animals whose shells were appropriated.

\section{Family Galatheidæ.}

Galacantha, A. Milne-Edwards.

31. Galacantha areolata, sp. n., Wood-Mason.

A fine species closely allied to Galacantha rostrata, A. Milne-Edwards, but differing in its more distinctly areolated and more coarsely granulated carapace, and by having the apex of the horizontal portion of the rostrum short and minutely bifid, as well as in some other particulars.

One male specimen from Station 97, 1310 fathoms.

Colour, including the corneæ, dull milky orange.

Length 46 millim.

\section{Munidopsis, Whiteaves.}

32. Munidopsis ciliata, sp. n., Wood-Mason.

Closely allied to Munidopsis brevimana, Henderson, differing in having the transverse scale-like elevations of the carapace (which apparently also differ in form and distribution) and the ridges of the abdomen fringed with forwardlydirected hairs ; and the lateral margins of the carapace armed with six spines, of which the foremost is only half the size of the supra-antennal, while the first of the four between the two divisions of the cervical groove is much larger than the supra-antennal, and the sixth is about the same size as the first and third.

One male specimen from Station 97, 1310 fathoms.

Colours in the fresh state milk-white.

Total length from apex of rostrum to apex of telson 35 millim.; length of carapace from posterior margin to apex of 
rostrum 18 millim.; breadth of carapace between posterior and second third 10.5 millim.; length of chelipeds 19 millim.; length of rostrum 5 millim.

\section{Munidopsis stylirostris, sp. n., Wood-Mason.}

Allied to Munidopsis curvirostra, Whiteaves, differing in the somewhat slenderer rostrum passing off more suddenly from the fore margin of the carapace; in the spine of the antero-lateral angle being larger; in the presence behind the root of the rostrum of a pair of minute forwardly-directed spinules supported on small eminences, in place of the pair of well-developed spines seen in the same position in the preceding and other species ; in the absence of medio-dorsal spines on the carapace and abdominal terga; and in the spinose chelipeds and legs. In the chelipeds the basipodite bears a spine at the apex of its hinder angle; the ischiopodite two near the apex, one below, the other above; the meropodite four, two above and two below, at the apex, besides three or four on the shaft towards the distal end; and the carpopodite also four in a similar position; while the chelæ, in which the fingers are equal in length to the palms, are unarmed. In the legs the carpopodite and meropodite each bear a spine at the upper apex. The corneæ appear to be narrower and more elongated, being distinctly cylindrical in the basal half.

Colour in the fresh state dull orange-pink, including the corneæ: in spirit pure ivory-white, with the non-faceted corneæ yellow.

Two female specimens from Station 105, 740 fathoms.

Total length 54 millim.; length of carapace 18.5 , of rostrum 11 millim.; breadth of carapace between tridentate lobes behind antero-lateral tooth 15.5 millim.; length of chelipeds 40 millim.

Elasmonotus, A. Milne-Edwards.

\section{Elasmonotus Edwardsii, sp. n., Wood-Mason.}

Body and all the appendages completely clothed with a dense velvety pubescence. The carapace is moderately convex in all directions, but especially transversely and over the gastric region, which is delimited from the bisected cardiac region and from the hepatic regions by a transverse groove. The rostrum is porrect, acute, triangular, with straight sides and roof-shaped dorsal surface. The anterior margin of the carapace is armed rather farther from the middle line than Ann. \& Mag. N. Hist. Ser. 6. Vol. vii. 
from the antero-lateral angle with a small triangular spine, the point of which is opposite the chink-like interval between the eyes and the antennal bases; the antero-lateral angle is slightly produced, and the interval between it and the supraantennal spine is roundly emarginate; the lateral margin is divided by two notches into two lobes, the anterior and shorter of which, answering to the interval between the two divisions of the cervical groove, is vertically compressed, somewhat expanded laterally, subacute at the edge, and produced anteriorly into a blunt tooth; the peduncles of the eyes are indistinguishably ankylosed together and immovably united with the rostrum and antennulary sternum, and give off from their inner side a long spine, which, being applied by its base to the under surface of the rostrum, presents the appearance of an orbital eave terminating anteriorly in a preocular spine, while the cornea on its outer side looks like an eye retracted into its orbit. The chelipeds and legs are short and stout; the ischiopodites of the former are armed at the apex above and below with one spine, the meropodites with four along their posterior angles (two on their inner and two on their outer apices), the carpopodites with one on the inner side; while the second, third, and fourth pairs of legs are armed on the upper margin of the meropodites with increasing series of seven, six, and five spines respectively, and on the upper margin of the carpopodites with three.

One male from Station 97, 1310 fathoms, the colour in the fresh state being milk-white, including the corneæ. In spirit the corneæ are yellow.

Total length 45 millim. ; length of carapace 24 millim., of rostrum, from rostro-ocular suture to apex, 6 millim.; breadth of carapace across anterior lobes $15 \cdot 4$, of chelipeds 24 millim.

It is a remarkable circumstance that no specimens of the genera Galathea, Munida, and Eumunida were obtained during: the past season, although in previous seasons specimens of one or other of them have not been uncommon in the trawl and on the tangles.

[To be continued.] 

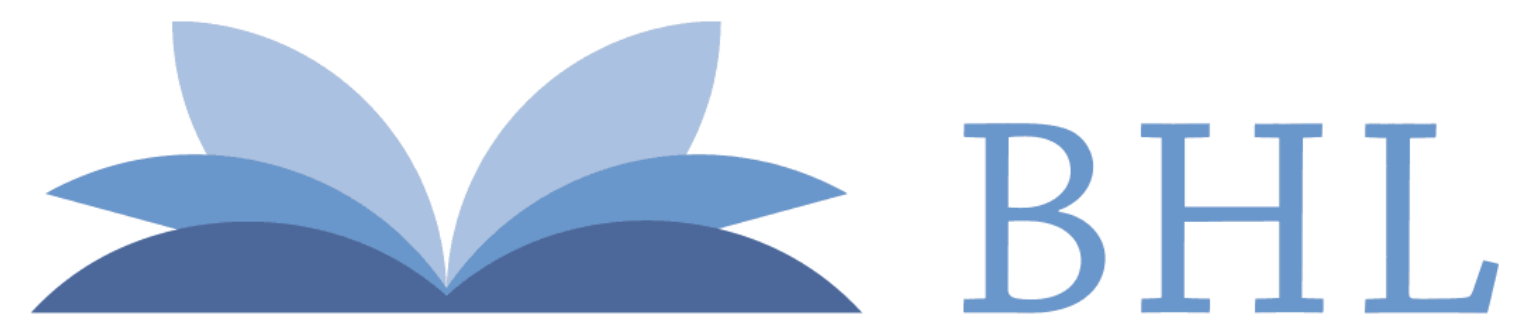

\section{Biodiversity Heritage Library}

Wood-Mason, James. and Alcock, A. 1891. "XXII.-Natural history notes from H.M. Indian Marine Survey Steamer 'Investigator,' Commander R. F. Hoskyn, R.N., commanding.-No. 21. Note on the results of the last season's deep-sea dredging." The Annals and magazine of natural history; zoology, botany, and geology 7, 186-202. https://doi.org/10.1080/00222939109460596.

View This Item Online: https://www.biodiversitylibrary.org/item/63422

DOI: https://doi.org/10.1080/00222939109460596

Permalink: https://www.biodiversitylibrary.org/partpdf/59182

\section{Holding Institution}

University of Toronto - Gerstein Science Information Centre

\section{Sponsored by}

University of Toronto

\section{Copyright \& Reuse}

Copyright Status: NOT_IN_COPYRIGHT

This document was created from content at the Biodiversity Heritage Library, the world's largest open access digital library for biodiversity literature and archives. Visit BHL at https://www.biodiversitylibrary.org. 